\title{
Theory of Social Representations: Educational Possibilities in the Development of Active Methodologies for Significant Learning*
}

\author{
Emanuella de Castro Marcolino', Gustavo Ávila Dias², \\ Francisco Arnoldo Nunes de Miranda ${ }^{3}$, \\ Mônica Gisele Costa Pinheiro ${ }^{4}$, Francisco de Sales Clementino ${ }^{5}$, \\ Clélia Albino Simpson ${ }^{6}$
}

\section{Abstract}

Background: The National Curriculum Guidelines reinforce the need for training of professionals with critical and reflective skills in addition to acquiring technical skills. Those criteria directly and indirectly relate to the desired professional profile, either in graduation scenarios or in postgraduate courses. The adoption of active methodologies in classrooms contributes to the training of health professionals able to provide clinical and epidemiological responses adequate to health-disease processes. In this perspective, this study aims to reflect, from reports, on the use of the theory of social representations as a pedagogical possibility in the development of active methodologies, and to build a meaningful learning.

Methods and Findings: This is an analytical study, with a qualitative approach, developed based on the statements of the experiences lived by students of the postgraduate program in nursing at the Federal University of Rio Grande do Norte. It discusses the relationship between the use of active methods of teaching and learning, meaningful learning and theory of social representations, created by Serge Moscovici. The assumptions and techniques that justify the concept and the research in the field of social representations were concurrently assimilated as the study object and as a methodological theoretical strategy, promoting the construction of teaching and learning processes based on educational practices and on the meaning shared by the subjects of the experienced reality.
1 Nurse (UEPB), student of Nursing Postgraduate program of the Federal University of Rio Grande do Norte (UFRN), Natal/RN, Brazil.

2 Nurse (UFS), Master in Social Anthropology (UFSC) and special student of the Graduate Program in Nursing of the Federal University of Rio Grande do Norte (UFRN), Natal/RN, Brazil.

3 Nurse, PhD in Nursing, Graduate Program Professor at Federal University of Nursing of Rio Grande do Norte (UFRN), Natal/RN, Brazil.

4 Nurse (UFRN), student of Nursing Postgraduate program of the Federal University of Rio Grande do Norte (UFRN), Natal/RN, Brazil.

5 Nurse, Doctor of Nursing at the Graduate Nursing program of the Federal University of Rio Grande do Norte (UFRN). Professor at the Federal University of Campina Grande, Campina Grande/PB, Brazil.

6 Nurse, Postdoctoral for University of Évora/PT, Professor of the Nursing Post-graduate Program at the Federal University of Rio Grande do Norte (UFRN), Natal/RN, Brazil.

*: Article built as a prerequisite for final evaluation in ENF2027 discipline. THEORY Of Social Representations offered by the graduate program in nursing at the Federal University of Rio Grande do Norte in the first half of 2015/02.

Contact information:

Gisele Costa Pinheiro.

झ monicapinheiro_@live.com 
Conclusions: The use of active methodologies was extremely favorable to the interaction, comprehension and production of knowledge of the involved subjects regarding the contribution to the study of social representations.

\section{Keywords}

Learning; Active

Methodologies; Social Theory;

Social Group; Nursing

\section{Introduction}

The quality of qualitative research in public health systems, especially in Latin America and the Caribbean, reflects the historical achievements of mankind, through advances in science, technology and innovation in the management of educational and health services, including the approach to socio-cultural, political and institutional aspects of those societies as a whole.

In Brazil, the ongoing global changes focus on the processes of teaching and learning and their investigations significantly affecting the health professions. The National Curriculum Guidelines of general nature reinforce those changes aimed at, through the training processes, meeting the general criteria of generality, criticality and reflexivity about care in the workplace and in the context of the Unified Health System [1, 2].

Those criteria directly and indirectly relate to the desired professional profile, either in graduation scenarios or in postgraduate courses. In this sense, one expects that the adoption of active methodologies and meaningful learning in the context of the classroom and in the Brazilian education system will contribute to the formation of health professionals, making them able to give clinical and epidemiological responses adequate to the health-disease processes [1, 3].

Social representations presuppose socially shared knowledge and meanings, built under the universes of common sense and science $[4,5]$. Such representations can be erected in their own educational and pedagogical spaces as objects of discussions, which also contain heuristic and polysemic aspects. The active methods fall into this perspective as an educational concept that encourages critical-reflective teaching-learning and proactivity processes [6].

In this study, social representations are designed not only as a reference through which one sought to understand the social phenomena, making the unfamiliar familiar; but, above all, as a pedagogical principle, limited by active methods to bring an ethical, critical, reflective and transformative educational practice $[6,7,8]$. The arrangement of teaching practices was designed as a potentially capable device to access psychosocial aspects of the subjects of the discipline "ENF2027 - Theory of Social Representations", offered by the Postgraduate Program in Nursing of the Federal University of Rio Grande do Norte.

Under such ideas and experiences, the motivation and the challenge about the possibility of conceptual triangulation emerged [9], as a pedagogical axis in the development and in the context of active methodologies for meaningful learning, raising the question: How can social representations pedagogically used contribute to the development of active methods with a view to significant learning?

Thus, the following objective arose: to reflect, from reports, on the use of the theory of social representations as a pedagogical possibility in the development of active methodologies, and to build a meaningful learning.

\section{Methods}

This is an analytical study, with qualitative approach, conducted based on the reports of the experiences 
from the pedagogical practices of the postgraduate program in nursing of the Federal University of Rio Grande do Norte. The theory of social representations entered in the arena of active methodologies and meaningful learning as the problematical character activities were developed.

The launched methodological proposal sought to promote the production of life and subjectivities linked to autonomy and the role of the participants, in addition to the sharing of their historical and social processes, in the representational point of view. In the academic context, the subjective and objective conditions loom large social and everyday peculiarities, favoring the acquisition of cognitive skills and abilities through perspectives and contemporary approaches [8].

Understanding the social representations starts, fundamentally, from the dialogue between consensual and reified science universe as social drivers and constituents of social thought in its dynamics and diversity. In this sense, the reified universe comprises theoretical and empirical assumptions related to science, shared by the scientific community; the consensual universe is the knowledge developed in day-to-day, universally known as common sense, which has the power to build beliefs, attitudes and opinions on the social environment $[10,11]$.

Therefore, the social representations base on two social cognitive processes - anchoring and objectification, which act in the interactional space against the object of interest. Anchoring is the process of finding a place, a reference to the unfamiliar, and occurs through the representation of the non-usual, in the familiar world, from known references; the objectification elaborates the image representation, the materialization of the abstract object [12].

The nature of an essentially social theory carries the complexity of its applicability, making it suitable to all objects socially placed. It is, currently, the analysis methodology of various fields of research by the ability to make concrete what seems invisible, revealing its interdisciplinary character and its appropriation for understanding phenomena of distinct orders, such as the advancement of knowledge in the nursing area $[5,7,13]$.

\section{Results}

There was a group dynamic as a proposed active methodology and of significant learning under the social representations, in which twine, whiteboard, marker and strips of paper were available and used.

The group members (students and professors) were randomly arranged in a circle. They had to identify themselves with a paper tag that was, later, placed in the corresponding seat frame. Then, each participant was asked to choose an attribute of his/ her personality, considered, by him/herself, in that learning scenario, the most emphatic among the other that formed them, and to register it with the tag under the name, as primary choice.

It is noteworthy that the adoption of that feature is a dynamic adaptation of the Technique of Free Association of Words (TALP) [14], which allowed to analyze, also in a playful way, the existing processes of identification among the discipline subjects, based on the combination of common and constituent qualitative elements of personality evoked by them. The concept of personality that contributes to this pedagogical perspective is a dynamic and structuring process inherent to subjectivity, erected over the life trajectories of individuals from experiences, feelings and patterns of constructed responses from a psychological maturation [15].

In possession of a string, the members were asked to choose two more attributes among those already initially evoked by other members, that is, already expressed in other tags. The criteria used for secondary and tertiary choices were the possible approaches to the attributes chosen by other participants, which are also supposed to be constitutive of social representations of the subjects. As randomly evoked attributes were being included in the set of attributes listed by the participants themselves, a 
string segment was consolidated, symbolizing the flow of the link between the members and their respective identifications. Thus, each participant, from the proposed dynamic, presented three words evoked on personality (Table 1).

Table 1. Distribution of the terms evoked by the participants in relevance level.

\begin{tabular}{|l|c|c|c|}
\hline Subjects & $\begin{array}{c}\text { Primary } \\
\text { Choice }\end{array}$ & $\begin{array}{c}\text { Secundary } \\
\text { Choice }\end{array}$ & $\begin{array}{c}\text { Tertiary } \\
\text { Choice }\end{array}$ \\
\hline Participant & & & \\
\hline 1 & Happiness & Friendship & Justice \\
\hline 2 & Justice & Determination & Sincerity \\
\hline 3 & Friendship & Sincerity & Happiness \\
\hline 4 & Sincerity & Justice & Friendship \\
\hline 5 & Determination & Happiness & Sympathy \\
\hline 6 & Sympathy & Sincerity & Determination \\
\hline & & Source: Prepared by the authors. \\
\hline
\end{tabular}

Generally, the characteristic that appeared the most at all three levels as representative of the subjects was "sincerity", followed by the words "happiness", "justice", "friendship", "determination"; at last, the less mentioned item was "sympathy".

From the attributes mentioned by the subjects, two analytical axes may constitute: axis 1 - expressiveness - which refers to the stated terms sheltering in the field of expression, namely, "happiness", "friendship", "sympathy"; axis 2 - rationality - which consisted of the terms "justice", "determination" and "sincerity". The rationality axis showed the greatest frequency of mention, demonstrating that axis represents the best the group.

In the plan subjacent to results, it is possible to sense how the group expresses, perceives and shares the subjectivities in varying degrees of approach and combination. Based on the perspective of the functions of social representations, Figure 1 shows the understanding of the dynamics reported from the basic elements that make up the social representations, approaching the figurative scheme proposed by Moscovici [16].

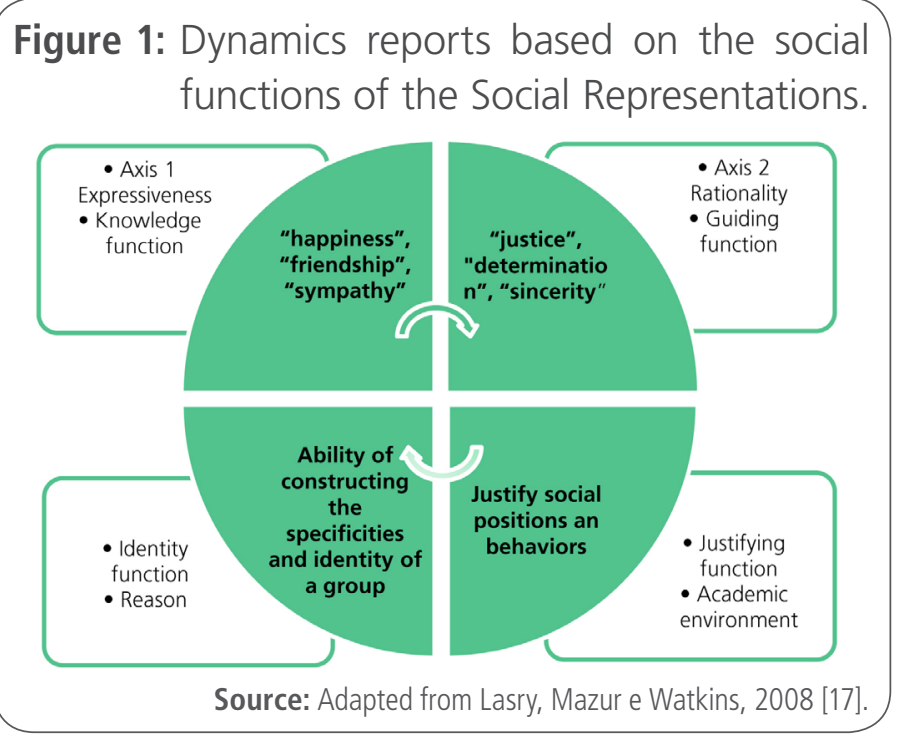

The resulting arrangement of the combination of the data from the dynamics were expressed graphically based on the panoramic plane figure composed of the obtained string segments expressed in Figure 2.

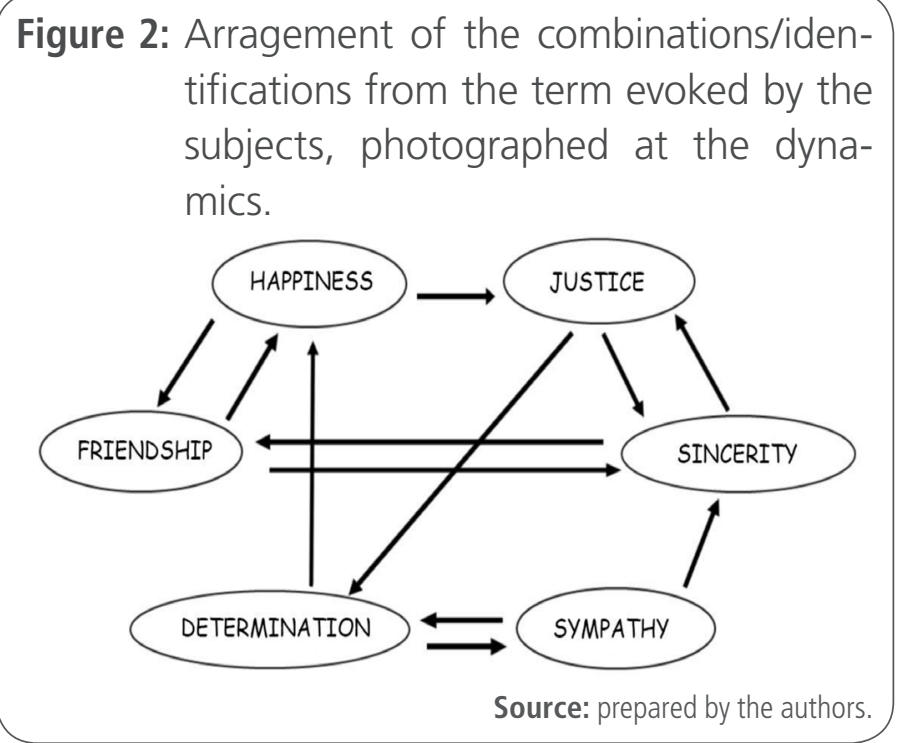

\section{Discussion}

Understanding the representations occurs procedurally and bases on four functions: knowledge function, which helps to explain the reality; the identity function, which would be the ability to build the specific characteristics and identity of a group; guiding function, which guides and leads 
social practices from the establishment of socially accepted; and justifying function, used to justify positions and social behaviors [11, 13].

The analysis of Table 1 allowed recognizing approaches to the functions of the theory of social representations, its applicability, senses and meanings produced from the group in question, by making the unknown - the personal characteristics of the group, from the traces of personalities evidenced by the dynamics - into something known by everyone, which refers to the principle of familiarization proposed by Moscovici [16], tracing the identity and justifying function for the formation of the group link, to meet the activity proposed by the group dynamics.

When one analyzes the identity and justifying function of the group in the context of social representations, one takes into account the maintenance of the identity, the influence of culture in groups, the symbolic possibilities of construction promoting social meanings that serve the realization of social practices [18]. Social representations have the following abilities: the first one is to standardize, that is, to make objects, people, events recognized by characteristics that locate them in a particular category, and gradually in a shared model for a group of people who join other models and synthesizes it; in the background, they also contribute in prescribing behaviors, influencing ways of thinking and acting, based on the mechanisms of reproduction without prior reflection, as an imposing force [16].

Thus, one observes that identity constructions happen through symbolic processes that are closely rooted to the social representations of groups, evoking the understanding of social identity, which constitutes their own social representations. One may mention the close theoretical basis between Social Representations and Social Identity, as they both seek three common issues: explaining and understanding social reality, justifying the positions and behaviors of individuals and defining the group identity [19].
In this sense, the social representations are responsible for characterizing social groups and allowing differing them. The members of a group build and share, in addition to social representations of personality attributes that define them, the social representations of objects linked to group values [20, 21]. Analyzing the features/adjectives/metaphors exposed by the participants allowed comprehending their identity elements; it is possible to see values that lead those individuals to compose the same group based on reflection on the social representations of the personality traits of the individuals who compose it.

Based on the understanding that metaphors can be understood as devices to provide functionality to the current social representations, they represent ways to indicate the presence or absence of social representations. In this sense, using the features/ adjectives/metaphors, they function as a means of grasping meanings [22].

Thus, the construction of the group identity according to the listed attributes, the object of representation in this study, one can say that the term "sincerity" assumes a centrality in social representation and allows declaring that the group essentially has that feature; moreover, that attribute works as a proxy link between the members and constituent of the group identity.

Thus, one sees the potential of Social Representations in the ability to build identities and represent groups; therefore, the theory of social representations is present in different fields and areas of knowledge, revealing its interdisciplinary character and its appropriation for understanding phenomena of distinct orders. An example of the fruitfulness of the theory of social representations stands out in a study that identified research groups registered in the National Council for Scientific and Technological Development $(\mathrm{CNPq})$ related to the theory of social representations revealing its potential to analyze the state of scientific literature [5]. Others claim that the representation of that issue in the Brazilian context 
contributes to the advancement of knowledge in the nursing area $[7,23]$.

\section{Conclusions}

The analysis of the group dynamics report used in the academic context, in the design of Social Representations as constitutive and possibility of active methodologies with a view to significant learning, expanded the perspective and reflection on the theoretical foundations of the proposed triangulation, and, perhaps, got close of how psychosocial subjects construct representational perspectives from their own discussed group.

In this process of apprehension of new knowledge, active learning methodologies function as catalysts, helping to articulate concepts and theoretical relationships, which allows the amplification of the look on the analyzed object and the actual construction of empirical knowledge from the learner. Nevertheless, the skills and competencies built by the students united to the objectives proposed by the discipline. Those skills and competences are tangent to the production of knowledge, meaning and significance given by the group about the spaces where learning was intentionally marked by the role and participation of the subjects.

This study may have contributed to the elucidation and clarification of the theoretical bases of the Social Representation applied to practical experience in order to demystify the complexity and learning of the theory. In contrast, one sought to show it as feasible and applicable to everyday reality, urging the practical exercise of applicability of the theory to every social phenomenon.

Furthermore, one deepened the ability of social representations of consolidating group identities elucidating the ties that keep the share of individuals in certain social groups through features/adjectives/metaphors in common. Therefore, one puts up the social representations as a key device in the understanding of group phenomena.
However, it is noteworthy that the process of understanding and learning in relation to the theory of social representations requires constant penetrations because it is a theory that shapes the conditions of reality and there is no, so to speak, recipe or precast paths to follow. Thus, at each object of study, a new challenge emerges.

\section{Abbreviations}

CNPq: Conselho Nacional de Desenvolvimento Científico e Tecnológico

TALP: Técnica de Associação Livre de Palavras

\section{References}

1. Erdmann AL, Fernandes JD, Teixeira GA. Panorama da educação em enfermagem no Brasil: graduação e pós-graduação. Enfermagem em Foco. 2011; 2(Suppl):89-93.

2. Mitre SM, Siqueira-Batista R, Girardi-de-Mendonça JM, MoraisPinto NM, Meirelles CAB, Pinto-Porto C, et al. Metodologias ativas de ensino-aprendizagem na formação profissional em saúde: debates atuais. Ciênc Saúde Coletiva. 2008; 13(Supll 2):2133-44

3. Dias HS, Lima LD, Teixeira M. A trajetória da política nacional de reorientação da formação profissional em saúde no SUS. Ciênc saúde coletiva. 2013; 18(6):1613-24.

4. Alves KL, Silva AO, Amaral AKFJ, Moura SG, Evangelista CB, Sá CMCP, et al. Theory of social representations and the aging: a bibliometric profile. International Archives of Medicine [Internet]. 2016 [cited 2016 Aug 12]; 9(147): [about 9 p.]. Available from: http://www.intarchmed.com/

5. Martins AM, Carvalho CAS, Antunes-Rocha MI. Pesquisa em representações sociais no Brasil: cartografia dos grupos registrados no CNPq. Psicol Teor Prat. 2014; 16(1):104-14.

6. Sobral FR, Campos CJG. Utilização de metodologia ativa no ensino e assistência de enfermagem na produção nacional: revisão integrativa. Rev Esc Enferm USP. 2012; 46(1):208-18.

7. Oliveira KKD, Maia CAAS, Miranda FAN. Teses e dissertações em enfermagem baseadas na teoria das representações sociais: análise bibliométrica. Rev Pesqui Cuid Fundam Online [Internet]. 2016 [cited 2016 Aug 12]; 8(1):[about 8 p.]. Available from: http://www.seer.unirio.br/index.php/cuidadofundamental/ article/view/4938

8. Melo TO, Tacahashi DS, Freitas PPS, Oliveira PN. O olhar do docente acerca dos alunos que trabalham inseridos nas metodologias ativas de aprendizagem. Rev Fac Ciênc Méd Sorocaba. 2014; 16(3):134-8. 
9. Gomes R, Souza ER, Minayo MCS, Malaquias JV, Silva CFR. Organização, processamento, análise e interpretação de dados: o desafio da triangulação. In: Minayo MCS, Assis SG, Souza ER. Avaliação por triangulação de métodos: Abordagem de Programas Sociais. Rio de Janeiro: Fiocruz; 2010. p. 185-221.

10. Pereira FJC. Estratégias de pesquisa pluri-metodológicas. In: Moreira ASP. Perspectivas teórico-metodológicas em representações sociais. João Pessoa: UFPB/Ed Universitária; 2005. p. 25-60

11. Azevedo DM, Costa RKS, Miranda FAN. Uso do alceste na análise de dados qualitativos: contribuições na pesquisa em enfermagem. Rev Enferm UFPE online [Internet]. 2013 [cited 2016 Aug 12]; 7(supll):[about 8 p.]. Available from: http://www. revista.ufpe.br/revistaenfermagem/index.php/revista/article/ view/3297/pdf 3089

12. Bôas LPSV. Uma abordagem da historicidade das representações sociais. Cad Pesqui. 2010; 40(140):379-405.

13. Reis SLA, Bellini M. Representações sociais: teoria, procedimentos metodológicos e educação ambiental. Humanand Social Sciences. 2011; 33(2)149-59.

14. Janczura GA. Contextos e normas de associação para palavras: a redução do campo semântico. Paidéia. 2005; 15(32):417-25.

15. Dalgalarrondo P. Psicopatologia e semiologia dos transtornos mentais. Porto Alegre: Artes médicas; 2008.

16. Moscovici S. Representações sociais: investigações em psicologia social. 5th ed. Petrópolis: Vozes; 2007.

17. Lasry N, Mazur E, Watkins J. Peer instruction: from Harvard to the two-year college. American Journal of Physics. 2008; 76(11):1066-9.

18. Seidmann S, Thomé S, Di Lorio J, Azzollini S. Construção identitária docente: reflexões a partir da teoria das representações sociais. In: Placco VMNS, Villas Bôas LPS, Souza CP. Representações sociais: diálogos com a educação. Curitiba: Champagnat; 2012. p. 43-56.

19. Martins-Silva PO, Souza EM, Silva Junior A, Nascimento DB, Balbi Neto RRQ. Adolescentes e homossexualidade: representações sociais e identidade social. Cadernos de Pesquisa. 2012; 42(146):474-93.
20. Breakwell GM. Social representations and social identity. Papers on Social Representations. 2003; 2(3):198-217.

21. Camargo BV, Campos PHF, Torres TL, Stuhler GD, Matão MEL. Representações sociais de saúde e cuidado: um estudo multicêntrico sobre vulnerabilidade masculina. Temas em Psicologia. 2011; 19(1):179-92

22. Miranda FAN. Representações sociais sobre a atuação do enfermeiro psiquiátrico no cotidiano [thesis]. Ribeirão Preto (SP): Universidade de São Paulo; 2002.

23. Silva SED, Camargo BV, Padilha MI. A Teoria das Representações Sociais nas pesquisas da enfermagem brasileira. Rer Bras Enferm. 2011; 64(5); 947-51.
Publish in International Archives of Medicine

International Archives of Medicine is an open access journal publishing articles encompassing all aspects of medical science and clinical practice. IAM is considered a megajournal with independent sections on all areas of medicine. IAM is a really international journal with authors and board members from all around the world. The journal is widely indexed and classified Q2 in category Medicine. 